\title{
Influence of the Crystal Growth Temperature on the Formation of Zr Reach Crystalline Phases in a Nuclear Waste Confinement Glass Ceramic
}

\author{
Dalila Moudir ${ }^{1}$, Nour-el-hayet Kamel ${ }^{1}$, Abdelbaki Benmounah ${ }^{2}$, Yasmina Mouheb ${ }^{1}$, Rafika Souag ${ }^{2}$, Boudjmaa \\ Bezzazi $^{2}$, Fairouz Aouchiche ${ }^{1}$, Ziane Kamel ${ }^{1}$ and Soumia Kamariz ${ }^{1}$ \\ 1. Algiers Nuclear Research Centre, Division of Nuclear Techniques, P.O.Box: 399, Alger-RP, Algiers, Algeria \\ 2. Research Unit on Materials, Processes and Environment (URMPE), University M'hamed Bouguerra, Avenue de l'indépendance, \\ 35000, Boumerdès, Algeria
}

Received: August 15, 2014 / Accepted: August 23, 2014 / Published: August 25, 2014.

\begin{abstract}
Many glass ceramics are potential candidates for the confinement of radioactive waste. This is the case of glasses embedding radiation-resistant ceramics as zirconolites, pyrochlores or pyroxenes. This study deals with the influence of the crystal growth temperature on the formation of such phases in a nuclear glass ceramic in the system: $\mathrm{Al}_{2} \mathrm{O}_{3}-\mathrm{SiO}_{2}-\mathrm{CaO}-\mathrm{MgO}-\mathrm{ZrO}_{2}-\mathrm{TiO}_{2}$. The materials with six contents of $\mathrm{ZrO}_{2}$, ranging from 1.00 to $6.40 \mathrm{~m} . \%$, are synthesized by a discontinuous method, consisting in a double-melting at $1,350{ }^{\circ} \mathrm{C}$, followed by both a nucleation at $564{ }^{\circ} \mathrm{C}$, and a crystal growth treatment at: 900,100 and $1,100{ }^{\circ} \mathrm{C}$. For the whole of the materials, the morphology reveals a glassy feature, with a opaque aspect. One can also evidence a different crystallization process from the bulk to the surface. The glass ceramics X-ray diffraction analysis (XRD) show that the main identified crystalline skeletons are those of: $2 \mathrm{M}$-zirconolite, $\mathrm{CaZrTi}_{2} \mathrm{O}_{7}$ and $\mathrm{ZrO}_{2}$, depending on the content of $\mathrm{ZrO}_{2}$ in materials and the crystal-growth temperature. The material with the middle content in $\mathrm{ZrO}_{2}(4.5 \mathrm{~m} . \%)$ and crystallized at the middle value of $\mathrm{Tc}\left(1,010{ }^{\circ} \mathrm{C}\right)$ show the greatest content in zirconolite $(87 \%)$, doped with either lanthanides or alcalin-earth elements, due to the complexity of the mixture of oxides. The temperature of $1,010^{\circ} \mathrm{C}$ appears to be more selective with regard to the formation of the $2 \mathrm{M}$-zirconolite.
\end{abstract}

Key words: Glass ceramic, radioactive waste, crystallization temperature, XRD, crystalline phase.

\section{Introduction}

The development of specific sequestration matrix designed to confine particular radionuclides is an important research field.

The industrial solution currently adopted for the confinement of the radiotoxic elements belonging to the nuclear waste, consists to incorporate them in a glass of the system: $\mathrm{SiO}_{2}-\mathrm{Al}_{2} \mathrm{O}_{3}-\mathrm{B}_{2} \mathrm{O}_{3}-\mathrm{Na}_{2} \mathrm{O}$. This confinement is not specific, and has the advantage of a good loading ability and an excellent long-term behavior [1].

Corresponding author: Moudir Dalila, researcher, research field: radioactive waste confinement materials. E-mail: dalilamoudir@yahoo.fr.
Various mineral matrices for the specific disposal of many radioisotopes produced from nuclear waste, particularly, for minor actinides (Mac), and fission products "lanthanides" (FP), include ceramics, such as zircon-titanates (zirconolite), zirconates (zirconia, stabilized zirconia, and phosphates (apatite, monazite) $[2,3]$.

The ceramics elaborating processes are difficult to implement to date, and many glass-ceramics are also under study. They consist of crystals homogeneously distributed in a glass matrix, and exhibit increased performances compared to alumino-borosilicate glasses.

Research on glass-ceramics (noted: GC) matrices for 
radioactive waste (RW) sequestration can benefit from both glass technology and interesting confinement properties of crystalline ceramic phases $[4,5]$.

In this study, we have synthesized a $\mathrm{ZrO}_{2}$-rich glass-ceramic by a discontinuous method, consisting in a double-melting at $1,350{ }^{\circ} \mathrm{C}$, followed by both a crystallization and crystal-growth, treatments at 564 and $1,010{ }^{\circ} \mathrm{C}$, respectively. In order to access the influence of the crystal-growth temperature on the nature of the germs born in the bulk of the GC materials, pellets of variable contents in $\mathrm{ZrO}_{2}$ are ceramized at three crystal-growth temperatures (Tc), namely: 900 , 1,010 and $1,100{ }^{\circ} \mathrm{C}$ during $3 \mathrm{~h}$. The crystalline phases analysis formed in the materials is performed by X-ray diffraction (XRD).

\section{Experiments}

The general GC mixtures chemical composition is inspired from previous research studies [6]. The samples are prepared with the following $\mathrm{ZrO}_{2}$ mass contents: $1.00,2.49,3.50,4.50,5.00,5.70$ and $6.40 \mathrm{~m} . \%$ (Table 1).

The employed commercial reagents were: $\mathrm{Al}_{2} \mathrm{O}_{3}$ (Fluka), $\mathrm{B}_{2} \mathrm{O}_{3}$ (Purity $\geq 99 \%$ ), $\mathrm{CaO}$ (Merck, $\geq 97 \%$ ), $\mathrm{CeO}_{2}$ (Aldrich, 99.999\%), $\mathrm{CrO}_{3}$ (Merck, $\geq 99 \%$ ), $\mathrm{Fe}_{2} \mathrm{O}_{3}$ (Merck, $\geq 99 \%$ ), $\mathrm{K}_{2} \mathrm{CO}_{3}$ (Merck, $\geq 99 \%$ ), $\mathrm{Li}_{2} \mathrm{O}$ (Merck, $\geq 99 \%$ ), $\mathrm{MgO}$ (Flucka, $\geq 97 \%$ ), $\mathrm{MnO}_{2}$ (Merck), $\mathrm{MoO}_{3}$ (Merck, $\geq 99.5 \%$ ), $\mathrm{Nd}_{2} \mathrm{O}_{3}$ (Fluka, $\geq 99.9 \%$ ), $\mathrm{P}_{2} \mathrm{O}_{5}$ (Merck, $\geq 98 \%$ ), $\operatorname{Pr}_{6} \mathrm{O}_{11}$ (Merck, $\geq 99 \%$ ), $\mathrm{SiO}_{2}$ (Prolabo), $\mathrm{Ta}_{2} \mathrm{O}_{5}$ (Merck, $\geq 99 \%$ ), $\mathrm{TiO}_{2}$ (Merck, $\geq 99 \%$ ), $\mathrm{V}_{2} \mathrm{O}_{5}$ (Labosi), $\mathrm{WO}_{3}$ (Merck), $\mathrm{Y}_{2} \mathrm{O}_{3}$ (Merck, $\geq$

Table 1 Chemical composition of the synthesized GC materials.

\begin{tabular}{|c|c|c|c|c|c|c|c|}
\hline \multirow{2}{*}{$\begin{array}{l}\text { Oxide (m.\%) } \\
\mathrm{ZrO}_{2}\end{array}$} & \multicolumn{7}{|c|}{ Content (\%) } \\
\hline & 1.000 & 2.487 & 3.500 & 4.500 & 5.000 & 5.700 & 6.400 \\
\hline $\mathrm{Al}_{2} \mathrm{O}_{3}$ & 12.948 & 12.948 & 12.948 & 12.948 & 12.948 & 12.948 & 12.948 \\
\hline $\mathrm{B}_{2} \mathrm{O}_{2}$ & 0.782 & 0.782 & 0.782 & 0.782 & 0.782 & 0.782 & 0.782 \\
\hline $\mathrm{BaO}$ & 0.586 & 0.586 & 0.586 & 0.586 & 0.586 & 0.586 & 0.586 \\
\hline $\mathrm{CaO}$ & 11.487 & 11.487 & 11.487 & 11.487 & 11.487 & 11.487 & 11.487 \\
\hline $\mathrm{CeO}_{2}$ & 3.113 & 3.113 & 3.113 & 3.113 & 3.113 & 3.113 & 3.113 \\
\hline $\mathrm{CrO}_{3}$ & 0.391 & 0.391 & 0.391 & 0.391 & 0.391 & 0.391 & 0.391 \\
\hline $\mathrm{Er}_{2} \mathrm{O}_{3}$ & 1.281 & 1.281 & 1.281 & 1.281 & 1.281 & 1.281 & 1.281 \\
\hline $\mathrm{Fe}_{2} \mathrm{O}_{3}$ & 1.281 & 1.281 & 1.281 & 1.281 & 1.281 & 1.281 & 1.281 \\
\hline $\mathrm{K}_{2} \mathrm{O}$ & 0.978 & 0.978 & 0.978 & 0.978 & 0.978 & 0.978 & 0.978 \\
\hline $\mathrm{La}_{2} \mathrm{O}_{3}$ & 0.489 & 0.489 & 0.489 & 0.489 & 0.489 & 0.489 & 0.489 \\
\hline $\mathrm{Li}_{2} \mathrm{O}$ & 4.105 & 4.105 & 4.105 & 4.105 & 4.105 & 4.105 & 4.105 \\
\hline $\mathrm{MgO}$ & 2.500 & 2.500 & 2.500 & 2.500 & 2.500 & 2.500 & 2.500 \\
\hline $\mathrm{MnO}_{2}$ & 0.195 & 0.195 & 0.195 & 0.195 & 0.195 & 0.195 & 0.195 \\
\hline $\mathrm{MoO}_{3}$ & 2.737 & 2.737 & 2.737 & 2.737 & 2.737 & 2.737 & 2.737 \\
\hline $\mathrm{Nd}_{2} \mathrm{O}_{3}$ & 1.173 & 1.173 & 1.173 & 1.173 & 1.173 & 1.173 & 1.173 \\
\hline $\mathrm{NiO}$ & 0.586 & 0.586 & 0.586 & 0.586 & 0.586 & 0.586 & 0.586 \\
\hline $\mathrm{P}_{2} \mathrm{O}_{5}$ & 0.391 & 0.391 & 0.391 & 0.391 & 0.391 & 0.391 & 0.391 \\
\hline $\mathrm{Pr}_{6} \mathrm{O}_{11}$ & 0.098 & 0.098 & 0.098 & 0.098 & 0.098 & 0.098 & 0.098 \\
\hline $\mathrm{SiO}_{2}$ & 47.427 & 45.940 & 44.927 & 43.927 & 43.427 & 42.727 & 42.027 \\
\hline $\mathrm{Ta}_{2} \mathrm{O}_{5}$ & 0.195 & 0.195 & 0.195 & 0.195 & 0.195 & 0.195 & 0.195 \\
\hline $\mathrm{TiO}_{2}$ & 4.790 & 4.790 & 4.790 & 4.790 & 4.790 & 4.790 & 4.790 \\
\hline $\mathrm{V}_{2} \mathrm{O}_{5}$ & 0.098 & 0.098 & 0.098 & 0.098 & 0.098 & 0.098 & 0.098 \\
\hline $\mathrm{WO}_{3}$ & 0.782 & 0.782 & 0.782 & 0.782 & 0.782 & 0.782 & 0.782 \\
\hline $\mathrm{Y}_{2} \mathrm{O}_{3}$ & 0.489 & 0.489 & 0.489 & 0.489 & 0.489 & 0.489 & 0.489 \\
\hline $\mathrm{Yb}_{2} \mathrm{O}_{3}$ & 0.098 & 0.098 & 0.098 & 0.098 & 0.098 & 0.098 & 0.098 \\
\hline Total & 100.00 & 100.00 & 100.00 & 100.00 & 100.00 & 100.00 & 100.00 \\
\hline
\end{tabular}


99\%), $\mathrm{Yb}_{2} \mathrm{O}_{3}$ (Aldrich, 99.9\%), $\mathrm{ZrO}_{2}$ (Aldrich, 99\%).

REE elements' oxides are dried over night at $1,000{ }^{\circ} \mathrm{C}$, and the other oxides at $400{ }^{\circ} \mathrm{C}$, for the same time. $\mathrm{BaO}$, $\mathrm{Er}_{2} \mathrm{O}_{3}, \mathrm{La}_{2} \mathrm{O}_{3}$ and $\mathrm{NiO}$ are prepared by calcination at $450{ }^{\circ} \mathrm{C}$ of $\mathrm{BaNO}_{3}$ (Fluka, 99.6\%), $\mathrm{ErN}_{3} \mathrm{O}_{9} \cdot 5 \mathrm{H}_{2} \mathrm{O}$ (Acros Organics, 99.9\%), $\mathrm{La}\left(\mathrm{NO}_{3}\right)_{3} \cdot 6 \mathrm{H}_{2} \mathrm{O}$ (Fluka, 99.99\%), and $\mathrm{Ni}\left(\mathrm{NO}_{3}\right)_{2} \cdot 6 \mathrm{H}_{2} \mathrm{O}$ (Fluka, 99.6\%), respectively.

The GC synthesis is carried out by a double-melting at $1,350{ }^{\circ} \mathrm{C}$. This is necessary to ensure a complete homogenization of the oxides mixture, to guarantee isotrope properties of the final products. The melts are poured in a graphite cylindrical mold to obtain pellets. The nucleation step is carried out at a nucleation temperature (Tn) of the parent glass, chosen as the glass transition temperature measured by differential thermal analysis $(\mathrm{Tg})$ plus $30{ }^{\circ} \mathrm{C}(\mathrm{Tn}=\mathrm{Tg}+30)$. $\mathrm{Tn}=564{ }^{\circ} \mathrm{C}$ for $2 \mathrm{~h}$. the crystal growth treatment (Tc) is performed at: $900,1,010$ and $1,100{ }^{\circ} \mathrm{C}$ for $3 \mathrm{~h}$, for the whole. The GC materials are cooled to the ambient air.
For the six studied compositions glasses, X-ray diffraction (XRD) analysis was conducted by a Philips X'Pert PRO apparatus, operating at CuK $\alpha 1$ wavelength $(\lambda K \alpha 1=0.15406 \mathrm{~nm})$. The analytical parameters were as follow: $\mathrm{V}=40 \mathrm{kV}$ and $\mathrm{I}=40 \mathrm{~mA}$; a $2 \theta$ scanning from $3^{\circ}$ to $80^{\circ}$. The XRD data were collected at room temperature on milled and sieved glass samples, with a mean size of $80 \mu \mathrm{m}$. For this, a $5657 \mathrm{Gmbh}$ Retsch automatic agath mortar was used. The crystalline phase (s) identification was done using the Philips X'Pert plus 2004 software [7].

\section{Results and Discussion}

\subsection{Characterization of the Materials}

The GC phase's identification was performed by XRD analysis, on thin blades from the bulk of the samples to avoid surface effects in the GC [8].

For the three Tc heat treatments and for the GC six chemical compositions studied, the XRD spectra are gathered in Figs. 1-7.

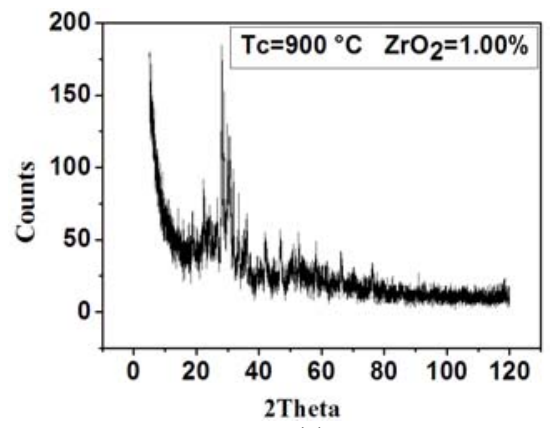

(a)

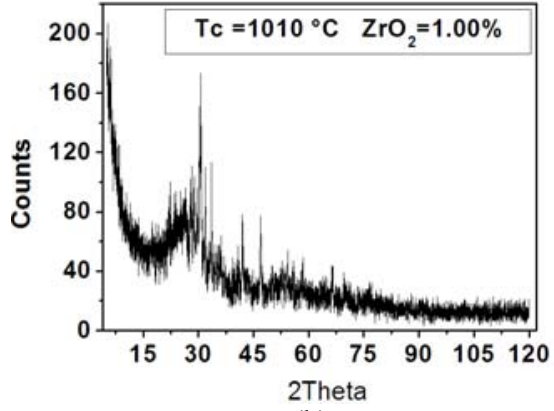

(b)

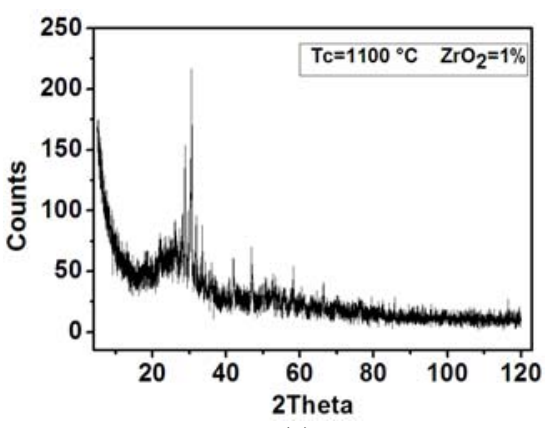

(c)

Fig. 1 Diffractogram of the GC with $1 \mathrm{~m} . \% \mathrm{ZrO}_{2}$ content. (a) $\mathrm{Tc}=900{ }^{\circ} \mathrm{C}$, (b) $\mathrm{Tc}=1,010{ }^{\circ} \mathrm{C}$ and $(\mathrm{c}) \mathrm{Tc}=1,100{ }^{\circ} \mathrm{C}$.

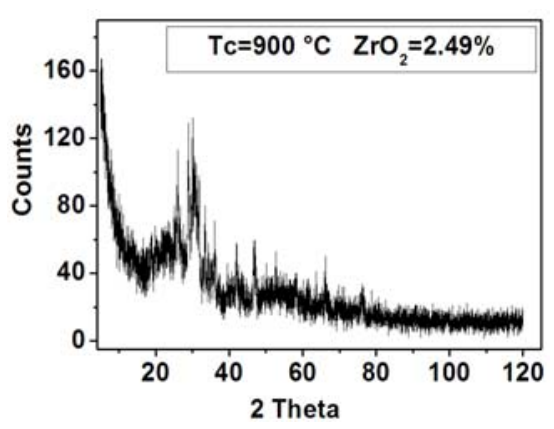

(a)

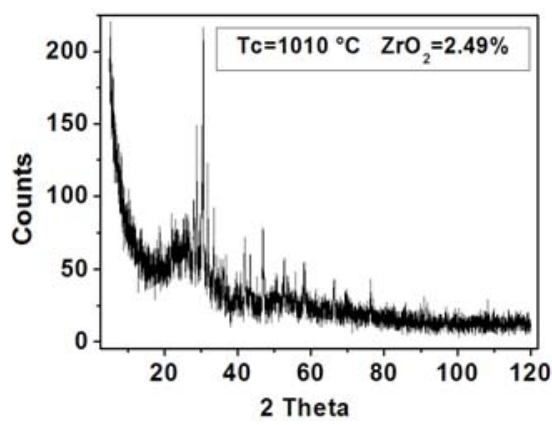

(b)

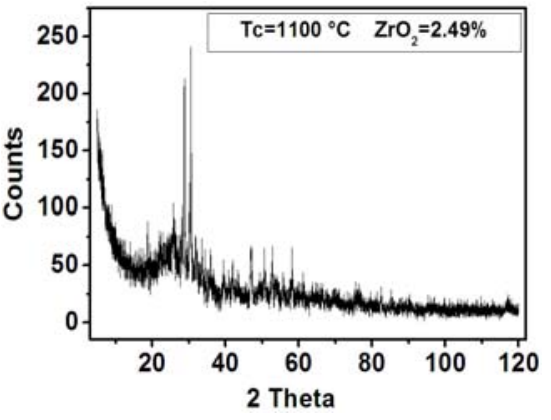

(c)

Fig. 2 Diffractogram of the GC with $2.49 \mathrm{~m} . \% \mathrm{ZrO}_{2}$ content. (a) $\mathrm{Tc}=900{ }^{\circ} \mathrm{C}$, (b) $\mathrm{Tc}=1,010{ }^{\circ} \mathrm{C}$ and (c) $\mathrm{Tc}=1,100{ }^{\circ} \mathrm{C}$. 
Influence of the Crystal Growth Temperature on the Formation of Zr Reach Crystalline Phases in a Nuclear Waste Confinement Glass Ceramic

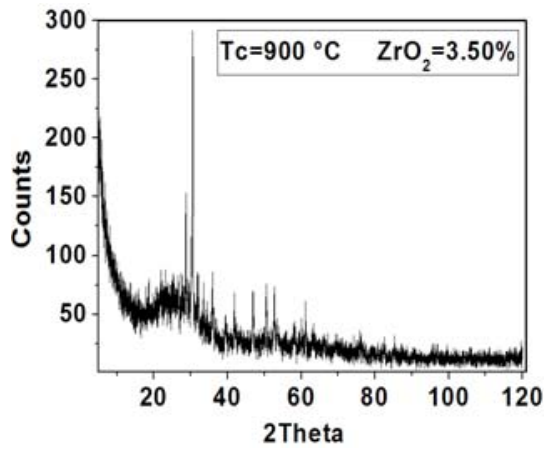

(a)

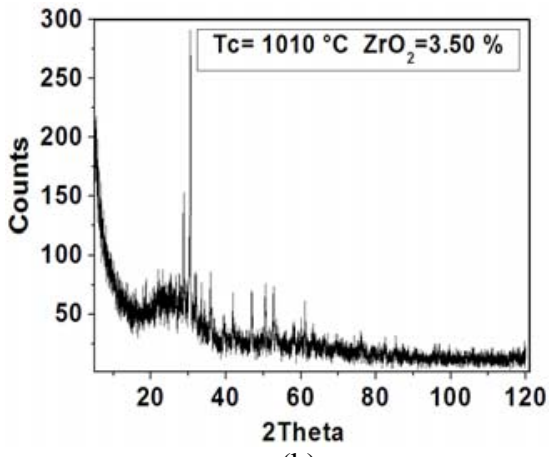

(b)

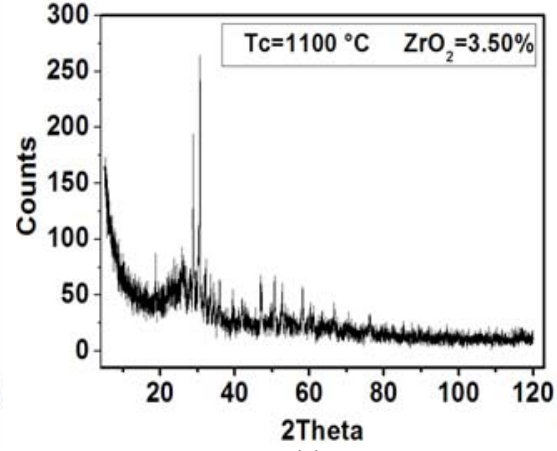

(c)

Fig. 3 Diffractogram of the GC with $3.50 \mathrm{~m} . \% \mathrm{ZrO}_{2}$ content. (a) $\mathrm{Tc}=900{ }^{\circ} \mathrm{C}$, (b) $\mathrm{Tc}=1,010{ }^{\circ} \mathrm{C}$ and (c) $\mathrm{Tc}=1,100{ }^{\circ} \mathrm{C}$.

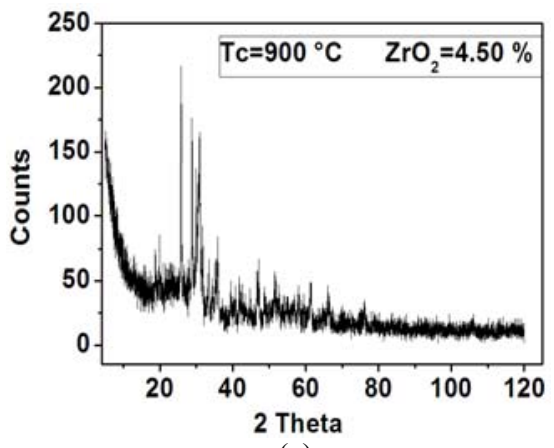

(a)

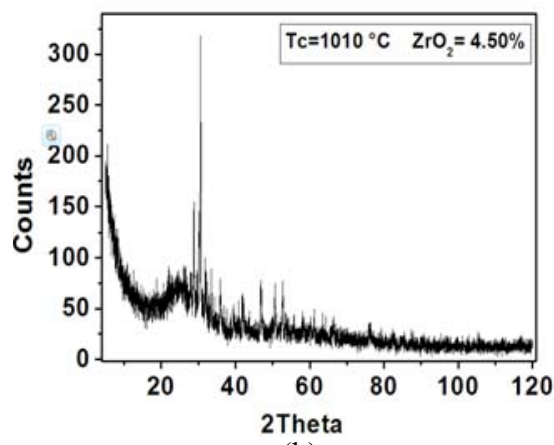

(b)

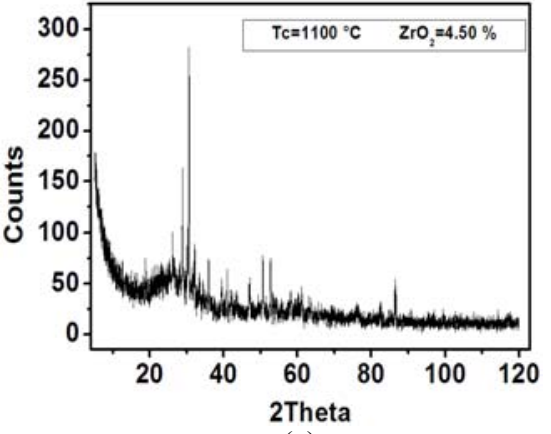

(c)

Fig. 4 Diffractogram of the GC with $4.50 \mathrm{~m} . \% \mathrm{ZrO}_{2}$ content. (a) $\mathrm{Tc}=900{ }^{\circ} \mathrm{C}$, (b) $\mathrm{Tc}=1,010{ }^{\circ} \mathrm{C}$ and (c) $\mathrm{Tc}=1,100{ }^{\circ} \mathrm{C}$.

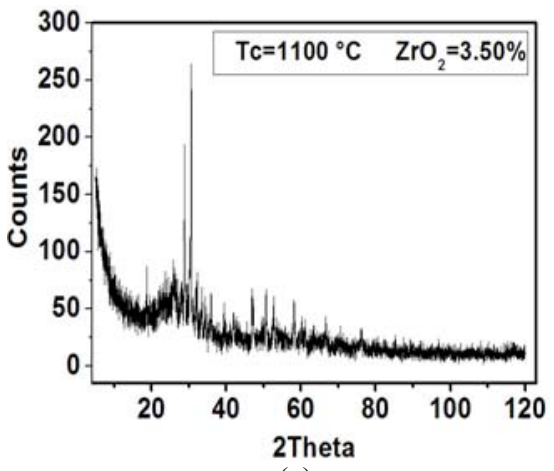

(a)

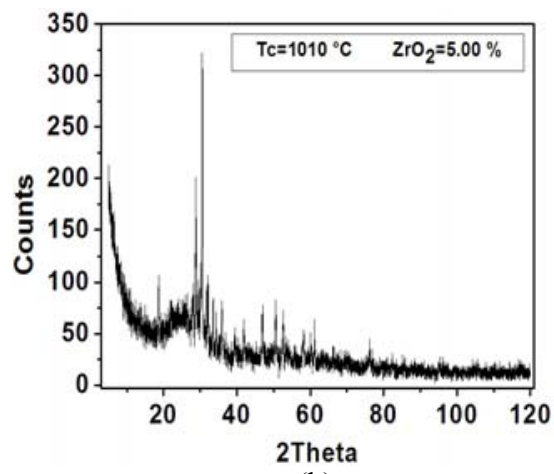

(b)

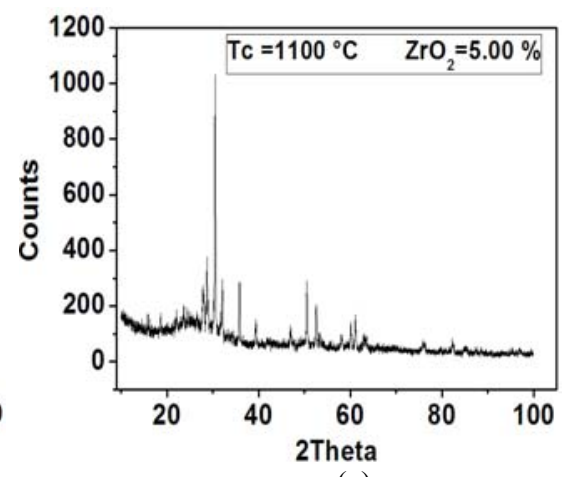

(c)

Fig. 5 Diffractogram of the GC with $5.00 \mathrm{~m} . \% \mathrm{ZrO}_{2}$ content. (a) $\mathrm{Tc}=900{ }^{\circ} \mathrm{C}$, (b) $\mathrm{Tc}=1,010{ }^{\circ} \mathrm{C}$ and (c) $\mathrm{Tc}=1,100{ }^{\circ} \mathrm{C}$.

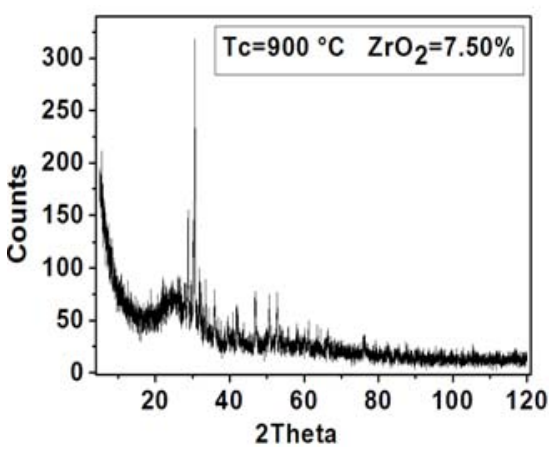

(a)

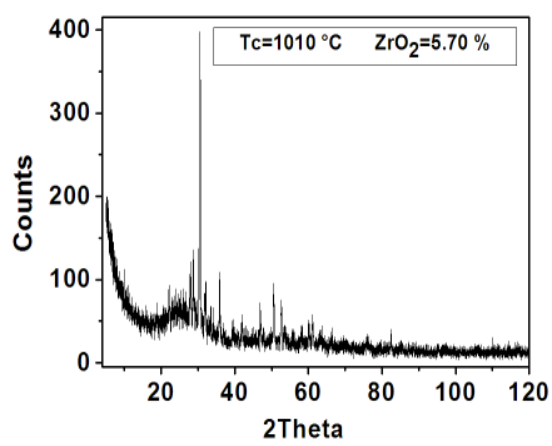

(b)

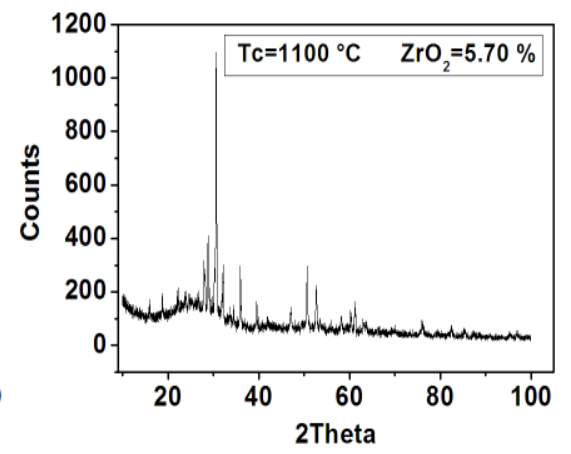

(c)

Fig. 6 Diffractogram of the GC with $5.70 \mathrm{~m} . \% \mathrm{ZrO}_{2}$ content. (a) $\mathrm{Tc}=900{ }^{\circ} \mathrm{C}$, (b) $\mathrm{Tc}=1,010{ }^{\circ} \mathrm{C}$ and (c) $\mathrm{Tc}=1,100{ }^{\circ} \mathrm{C}$. 

Nuclear Waste Confinement Glass Ceramic

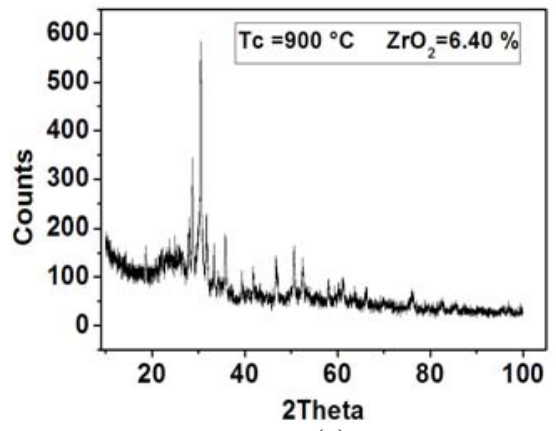

(a)

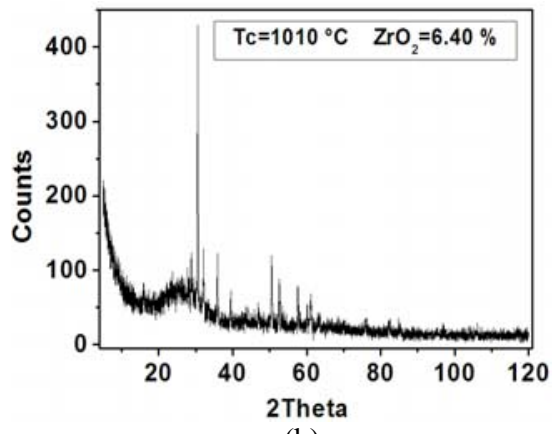

(b)

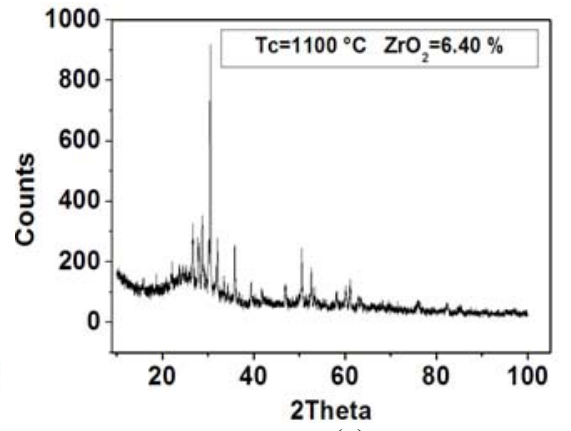

(c)

Fig. 7 Diffractogram of the GC with $6.40 \mathrm{~m} . \% \mathrm{ZrO}_{2}$ content. (a) $\mathrm{Tc}=900{ }^{\circ} \mathrm{C}$, (b) $\mathrm{Tc}=1,010{ }^{\circ} \mathrm{C}$ and $(\mathrm{c}) \mathrm{Tc}=1,100{ }^{\circ} \mathrm{C}$.

At the lowest crystal-growth temperature of $900{ }^{\circ} \mathrm{C}$, and for the lowest levels of $\mathrm{ZrO}_{2}$ in the GCs, there are few Zr-containing phases (especially zirconolite $\mathrm{CaZrTi}_{2} \mathrm{O}_{7}$ ) in the germinated crystals: $\mathrm{CaZrTi}_{2} \mathrm{O}_{7}$ (JCPDS: 00-034-0167), $\mathrm{ZrO}_{2}$ (JCPDS: 01-073-1441), $\mathrm{ZrTiO}_{4}$ (JCPDS: 01-074-1504), $\mathrm{Nd}_{2}\left(\mathrm{Ce}_{0.05} \mathrm{Zr}_{0.95}\right)_{2} \mathrm{O}_{7}$ (JCPDS:01-078-1619), ZrTi) O (JCPDS:01-080-1783),

$$
\left(\mathrm{Ca}_{0.85} \mathrm{Nd}_{0.075} \mathrm{Zr}_{0.075}\right) \quad\left(\mathrm{Nd}_{0.075} \mathrm{Zr}_{0.775} \mathrm{Ti}_{0.15}\right) \quad\left(\mathrm{Ti}_{2} \mathrm{O}_{7}\right)
$$
(JCPDS: 01-081-1491), ZrO $\mathrm{rO}_{1.95}$ (JCPDS: 01-081-1544), $\mathrm{Zr}_{0.86} \mathrm{Y}_{0.14} \mathrm{O}_{1.93}$ (JCPDS: 01-082-1243), $\mathrm{Ca}_{0.15} \mathrm{Zr}_{0.85} \mathrm{O}_{1.85}$ (JCPDS: 01-084-1829).

They reach a significant concentration, when the content of $\mathrm{ZrO}_{2}$ in the ceramic reaches $3.50 \%$.

At the intermediate temperature of crystallization $\left(1,010^{\circ} \mathrm{C}\right)$, the $\mathrm{Zr}$-reach phases are the main crystalline germs in the materials, even for the lowest content in of $\mathrm{ZrO}_{2}(1 \%)$.

However, it is only over $2.49 \mathrm{~m} . \%$ of $\mathrm{ZrO}_{2}$ in the GC material that the zirconolite skeleton $\mathrm{CaZrTi}_{2} \mathrm{O}_{7}$ appears with a significant concentration. The most VC materials contain over $65 \mathrm{~m}$. \% of zirconolite jointly with other additive $\mathrm{Zr}$-containing phases.

For $\mathrm{Tc}=1,100{ }^{\circ} \mathrm{C}$, the most crystals formed in the bulk of the GC materials are $\mathrm{Zr}$ oxides for the whole of $\mathrm{ZrO}_{2}$ contents in the materials, with a great content in 2M-zirconolite over $4.5 \mathrm{~m} . \%$ of $\mathrm{ZrO}_{2}$ in the GC matrices.

\subsection{Discussion}

Loiseau and Caurant et al. [9] have synthesized Zr-rich GC materials. They report the co-existence of germs of zirconolite and $\mathrm{ZrO}_{2}$ fluorine crystals, with a
Tc temperature of $1,000{ }^{\circ} \mathrm{C}$. The fluorine structure shows a very muddled distribution of $\mathrm{Ca}^{2+}, \mathrm{Zr}^{4+}$ and $\mathrm{Ti}^{4+}$ cations in zirconolite. This muddle distribution is attenuated when Tc increases [10].

For the present study, the zirconolite is the main formed phase in the bulk of the GC materials for the Tc temperature of $1,010{ }^{\circ} \mathrm{C}$, which is near this given by Loiseau and Caurant et al. [9] despite the differences in the nature of the GC materials and the synthesis parameters.

The best crystal-growth treatment in term of selectivity toward the 2M-zirconolite formation seems to be that of $1,010^{\circ} \mathrm{C}$.

One can conclude that the lowest crystal-growth temperature $\mathrm{Tc}=900{ }^{\circ} \mathrm{C}$ does not favor the germination of $\mathrm{Zr}$-rich phases, particularly zirconolite. The intermediate Tc temperature of $1,010^{\circ} \mathrm{C}$, leads to the greatest selective formation of zirconolite in the GC materials.

However, 900 and $1,100{ }^{\circ} \mathrm{C}$ also lead to the germination of radiation resistant phases rich in $\mathrm{Zr}$, and thus may ensure a double-confinement of the lanthanides and actinides present in the radioactive waste solution [9].

\section{Conclusions}

In this study, we performed the synthesis and characterization of $\mathrm{Zr}$-reach GC materials dedicated for the confinement of radioactive waste. The parent glass is an aluminosilicate glass in the system: $\mathrm{SiO}_{2}-\mathrm{Al}_{2} \mathrm{O}_{3}-\mathrm{CaO}-\mathrm{MgO}-\mathrm{ZrO}_{2}-\mathrm{TiO}_{2}$.

The synthesis method is based on a double melting at 


\section{Nuclear Waste Confinement Glass Ceramic}

$1,350{ }^{\circ} \mathrm{C}$, followed by a nucleation at $564{ }^{\circ} \mathrm{C}$ and a crystal growth at: $900,1,010$ and $1,100{ }^{\circ} \mathrm{C}$. The obtained results allow concluding that the $\mathrm{GC}$ materials exhibit typical properties compared to those of the glass matrix, because they contain highly self-irradiation resistant phases, such as zirconolite. Thus, these materials are potential candidates as nuclear waste forms for double-containment of actinides and lanthanides. For the whole of the studied chemical compositions of the materials, and for the three chosen $\mathrm{Tc}$ treatments, a Zr-reach crystalline phase, the $2 \mathrm{M}$-zirconolite $\left(\mathrm{CaZrTi}_{2} \mathrm{O}_{7}\right)$, was identified by XRD analysis, with high levels over $60 \%$ for the lowest $\mathrm{ZrO}_{2}$ content in the materials. Minor phases as zirconia $\left(\mathrm{ZrO}_{2}\right)$ and zircon $\left(\mathrm{ZrSiO}_{4}\right)$ are also observed.

The highest content in zirconolite $(87 \%)$ is reached for the $\mathrm{GC}$ with $4.5 \mathrm{~m} . \%$ of $\mathrm{ZrO}_{2}$. The lowest crystallization temperature $\left(900{ }^{\circ} \mathrm{C}\right)$ does not promote the germination of Zr-rich phases, especially zirconolite. This is intermediate crystal-growth temperature of $1,010{ }^{\circ} \mathrm{C}$, which leads to the greatest selectivity in zirconolite ceramic germination. However, the crystal-growth temperatures of 1,010 and $1,100{ }^{\circ} \mathrm{C}$ also result in germination of $\mathrm{Zr}$-reach radiation resistant phases.

\section{References}

[1] A. Jouan, N.J. Francillon, J.P. Moncouyoux, Vitrification of radioactive high-level waste in France, Status and Perspectives Source: Glass 3 (4) (1997) 4-10.

[2] F.P. Glasser, The role of ceramics, cement and glass in the immobilization of radioactive wastes, British Ceramic Transactions Journal 84 (1) (1985) 1-8.

[3] I.W. Donald, B.L. Metcalfe, R.N.J. Taylor, The immobilization of high level radioactive wastes using ceramics and glasses, Journal of Materials Science 32 (22) (1997) 5851-5887.

[4] P.J. Hayward, The use of glass ceramics for immobilising high level wastes from nuclear fuel recycling, Glass Technologie 29 (4) (1988) 122-136.

[5] P.J. Hayward, Glass-ceramics in Radioactive Waste Forms for the Future, Elsevier Science Publishers B. V., 1988, pp. 427-493.

[6] N. Kamel, D. Moudir, Z. Kamel, A. Djerridi, S. Mouhamou, A. Benmounah, et al., Effect of the Ce content on a nuclear waste glassy matrix in the system: $\mathrm{SiO}_{2}-\mathrm{Al}_{2} \mathrm{O}_{3}-\mathrm{CaO}-\mathrm{MgO}-\mathrm{ZrO}_{2}-\mathrm{TiO}_{2}$, synthesized at a low melting temperature, Journal of Materials Science and Engineering A 3 (4) (2013) 209-223.

[7] JCPDS Data Philips X'Pert High Score Package, Diffraction data CD-ROM, International Center for Diffraction Data, Newtown Square PA, 2004.

[8] R. Jenkins, R.L. Snyder, Introduction to X-Ray Powder Diffraction, Wiley, Interscience, 1996.

[9] P. Loiseau, D. Caurant, O. Majerus, N. Baffier, C. Fillet, Crystallization study of $\left(\mathrm{TiO}_{2}, \quad \mathrm{ZrO}_{2}\right)$-rich $\mathrm{SiO}_{2}-\mathrm{Al}_{2} \mathrm{O}_{3}-\mathrm{CaO}$ glasses Part $\mathrm{I}$ : Preparation and characterization of zirconolite-based glass-ceramics, Journal of Materials Science 38 (2003) 843-852.

[10] E.R. Vance, C.J. Ball, M.G. Blackford, D.J. Cassidy, K.L. Smith, Crystallisation of zirconolite from an alkoxide precursor, Journal of Nuclear Materials 175 (1990) 58-66. 